\title{
Screening of Bio-active Pigments, Antioxidant Activity, Total Phenolic and Flavonoid Content of Some Economically Important Medicinal Plants for Ethno-botanical Uses
}

\author{
Md. Abdul Hâkim ${ }^{1, a}$, Mohammed Arif Sadık Polash ${ }^{2, b, *}$, M. Ashrafuzzaman ${ }^{1, c, *}$, Md. Solaiman Ali Fakir,d, \\ ${ }^{1}$ Department of Crop Botany, Bangladesh Agricultural University, 2202 Mymensingh, Bangladesh \\ ${ }^{2}$ Department of Crop Botany, Khulna Agricultural University, 9202 Khulna, Bangladesh
}

*Corresponding author

A R T I C L I N F O A B S T R A C T

Research Article

An experiment was conducted to determinate the phytochemical properties (chlorophyll-a, chlorophyll-b, carotenoids, antioxidant activity, total phenolic and flavonoid content) in ten medicinal plants namely Syal Kata (Argemone mexicana L.), Akanda (Calotropis gigantea (L.) Dryand.), Dumur (Ficus carica L.), Chalmugra (Gynocardia odorata R.Br.), Kata kachu (Lasia

Received : 17/02/2021

Accepted : 08/03/2021 spinosa (L.) Thwaites), Shetodrone (Leucas aspera (Wild.)), Khona (Oroxylum indicum (L.) Kurz), Reri (Ricinus communis L.), Ghat kachu (Typhonium trilobatum (L.) Schott) and Bazna (Zanthoxylum rhetsa DC.) for ethno-botanical uses. The young fresh leaves were harvested and were subjected to methanolic $(95 \%)$ extract. Total phenolic contents were analysed by using Folin - Ciocalteau method where gallic acid was used as standard. Total phenolic content varied from $94.53 \mathrm{mg} \mathrm{GAE} / 100 \mathrm{~g} \mathrm{FW}$ (C. gigantea) to $484.88 \mathrm{mg} \mathrm{GAE} / 100 \mathrm{~g} \mathrm{FW}$ (L. aspera). Total flavonoid

Keywords:

Antioxidant activity Bio-active pigments Flavonoid Free radicals Total phenolic contents were performed by using Quercetin as standard. Total flavonoid content varied from 137.25 mg QUE /100 g FW (C. gigantea) to 334.27 mg QUE/100 g FW (G. odorata). Antioxidant activity of these extracts was performed by using DPPH free radical scavenging assay. Total antioxidant capacity varied from $\mathrm{IC}_{50}$ value $35.37 \mathrm{mg} / \mathrm{mL}$ (A. mexicana) to $90.47 \mathrm{mg} / \mathrm{mL}$ (F. carica) where ascorbic acid is used as standard. Results indicated that among the ten medicinal plants phenolics rich in L. aspera, flavonoids rich in G. odorata, antioxidant activity rich in A. mexicana. Z. rhetsa leaf rich in chlorophyll-a content $(311.67 \mathrm{mg} / 100 \mathrm{~g} \mathrm{FW})$, L. aspera leaf rich in chlorophyll-b content $(157 \mathrm{mg} / 100 \mathrm{~g} \mathrm{FW})$, Z. rhetsa rich in chlorophyll- $(\mathrm{a}+\mathrm{b})$ content as 439 $\mathrm{mg} / 100 \mathrm{~g} \mathrm{FW}$, A. mexicana leaf rich in carotenoids content as $96 \mathrm{mg} / 100 \mathrm{~g} \mathrm{FW}$.

\section{Introduction}

Generation of free radicals such as reactive oxygen species (ROS) and reactive nitrogen species (RNS) (Yagi, 1987; Finkel and Holbrook, 2000; Pham-Huy, He and Pham-Huy, 2008) is the consequence of lipid peroxidation which is mandatory and a normal physiological process in living systems (Hargguchi, 2001; Korkmaz et al., 2018). Free radicals have been associated with DNA damage carcinogenesis, coronary heart disease, and many other health problems related to advancing age, anemia, asthma, arthritis, inflammation, neurodegeneration, mutagenesis, alzheimer's and AIDS as well (Potterat, 1997; Das and Nanda, 1999; Cadenas and Davies, 2000; Marnett, 2000; Uchida, 2000; Devasagayam et al., 2004; Yingming et al., 2004; Sevindik, 2020). In vitro studies and findings strongly advocate that anti-oxidation potential have resilient protective effects against the stated diseases (Steinberg,
1991; Block et al., 1992; Ames et al., 1993; Knekt et al., 1997; Elliot, 1999; Kaur and Kapoor, 2002). Synthetic antioxidants viz. butylated hydroxyanisole (BHA), butylated hydroxytoluene (BHT) and propyl gallate which are most widely used being restricted due to their probable health risks and side effects (Caillet et al., 2006; Kumaran and Karunakaran, 2007). Therefore, the exploration for antioxidants from natural resources has gained much consideration, and efforts have been made to identify new natural resources for active antioxidant compounds from plants. Plant secondary metabolite such as phenolic and flavonoids exhibit free radical inhibition, peroxide decomposition, metal inactivation or oxygen scavenging in biological systems and prevent oxidative disease burden (Amadò et al., 2002; Oberoi et al., 2015; Sevindik et al., 2017; Mohammed et al., 2019) 
Medicinal plants-derived phenol, flavonoids and antioxidants which are in the form of raw extracts and/or chemical constituents are very proficient to inhibit the process of oxidation by neutralizing the free radicals (Zengin et al., 2011; Sevindik, 2018; Akgül et al., 2020). Among the 7000 species of medicinal plants recognized all over the world, more than 500 types of precious medicinal plants are said to be found in Bangladesh. We have selected ten most important and commonly used medicinal plants for our study. The selected medicinal plants were: Syal Kata $(A$. mexicana) indigenous in mexico use to control malarial fever, leprosy, cold sores, wound healing, skin diseases and jaundice (Dash and Murthy 2011), Akanda (C. gigantea) cures intermittent fever, cold, cardio tonic, asthma, scabies etc. (Singh et al., 2014), Dumur (F. carica) is use in cancer treatment, hypoglycemic, and antimicrobial activities (Veberic et al., 2008), Chalmugra (G. odorata) use in skin disease, Kata kachu (L. spinosa) helpful for skin, Shetodrone (L. aspera) controls chronic skin eruptions and chronic rheumatism (Dash et al., 2014), Khona (O. indicum) is curing to inflammation, asthma, dysentery, vomiting etc (Deka et al., 2013), Reri (R. communis) is used to treat diarrhea, dysentery and skin infections (Pandhure, 2014), Ghat kachu (T. trilobatum) is traditionally prescribed for gastric ulcer, headache, swelling, chronic bronchitis etc. (Ali et al., 2012) and Bazna (Z. rhetsa) is known for curing bronchitis, heart troubles, piles and toothache (Ghani, 2003).

The main purpose of this study was to evaluate the bio active pigments, free radical scavenging activity, total phenolic and flavonoid content of ten commercially important medicinal plants for free radicals scavenging purposes.

\section{Materials and Methods}

\section{Sample Collection}

Plant samples A. mexicana, C. gigantea, F. carica, G. odorata, L. spinosa, L. aspera, O. indicum, R. communis, $T$. trilobatum, Z. rhetsa were collected from Bangladesh Agricultural University Botanical Garden in the ziploc bag and brought to the plant physiology laboratory, Department of Crop Botany, Bangladesh Agricultural University, Mymensingh and stored for further chemical analyses.

\section{Reagents}

Folin-Ciocalteu reagent, Sodium carbonate, DPPH (2, 2-diphenyl-2-Picrylhydrazyl), Quercetin, potassium acetate, Aluminium Chloride.

\section{Parameter Determination}

\section{Spectrophotometric Pigments Determination}

Chlorophyll a, b and total carotenoids were determined according to the modification of the procedure stated by (Lichtenthaler, 1987). In brief, $1 \mathrm{gm}$ fresh leaf or fruit samples were taken in glass bottles and $25 \mathrm{~mL}$ acetone added and shaken properly and the content kept in the dark condition for overnight. Absorbance reading was taken in the next day in spectrophotometer (DR-6000, Hach, USA) at 470, 649, 666 and $750 \mathrm{~nm}$ wave lengths. Afterward, amount of chlorophyll a, chlorophyll b, chlorophyll $(a+b)$ and total carotenoids (sum of carotene and xanthophyll) were calculated using the following formulae and expressed as $\mathrm{mg} / 100 \mathrm{~g}$ fresh weight.

$$
\begin{aligned}
& \text { Chlorophyll a }\left(\mathrm{C}_{\mathrm{a}}\right)=\left(13.36 \mathrm{~A}_{666}-5.19 \mathrm{~A}_{649}\right) \times 25 / \mathrm{FW} \\
& \text { Chlorophyll b }\left(\mathrm{C}_{\mathrm{b}}\right)=\left(27.43 \mathrm{~A}_{649}-8.12 \mathrm{~A}_{666}\right) \times 25 / \mathrm{FW}
\end{aligned}
$$

Total Chlorophyll $\left(\mathrm{C}_{\mathrm{a}+\mathrm{b}}\right)=\left(5.24 \mathrm{~A}_{666}+22.24 \mathrm{~A}_{649}\right) \times 25 / \mathrm{FW}$

Carotenoids $\left(\mathrm{C}_{\mathrm{X}+\mathrm{C}}\right)=\left(4.785 \mathrm{~A}_{470}+3.657 \mathrm{~A}_{666}-12.76\right.$

$$
\left.\mathrm{A}_{649}\right) \times 25 / \mathrm{FW}
$$

Where;

$\mathrm{A}_{649}=$

$\mathrm{A}_{664}=$

$\mathrm{A}_{470}=$

$\mathrm{FW}=$
Absorbance at $649 \mathrm{~nm}$
Absorbance at $664 \mathrm{~nm}$
Absorbance at 470 run
Fresh weight of plant tissue extracted (mg)

DPPH Radical Scavenging Capacity Assay

The antioxidant activity of extracts, based on the scavenging activity of the stable DPPH free radical, was determined by the modified method described by Lee et al. (Lee et al., 2004). Exactly $2.5 \mathrm{~g}$ of composite leaf samples were weighing out to a $250 \mathrm{~mL}$ beaker and $50 \mathrm{~mL}$ methanol added and then homogenized plant samples for 2-3 minutes using OV-5 Homogenizer, VELP, Italy. The mixture was kept for 30 minutes in the dark condition. Immediately after darkness the content centrifuged for 5 minutes at 5000 $\mathrm{rpm}$ and then extract was separated for determining DPPH radical scavenging activity. The assay contained $3 \mathrm{~mL}$ of $40 \mu \mathrm{g} / \mathrm{ml} \mathrm{DPPH}$ in methanol and made up to $5 \mathrm{~mL}$ with $2 \mathrm{ml}$ plant extracts. The contents were mixed well immediately and then incubated for $30 \mathrm{~min}$ at room temperature $\left(25-27^{\circ} \mathrm{C}\right)$ at dark condition. The degree of reduction of absorbance was recorded at $517 \mathrm{~nm}$ using DR 6000 UV-Spectrophotometer.

The percentage of scavenging activity/inhibition activity was calculated and expressed as $\mathrm{mg} / \mathrm{ml}$.

$$
\% \text { Inhibition }=\left[\left(\mathrm{A}_{0}-\mathrm{A}_{1}\right) / \mathrm{A}_{0}\right] \times 100
$$

Where;
$\mathrm{A}_{0}=$ extract)
$\mathrm{A}_{1}=\quad$ Is the absorbance of sample. Percentage of radical scavenging activity was plotted against the corresponding concentration of the extract to obtain $\mathrm{IC}_{50}$ value.
$\mathrm{IC}_{50}=\quad$ Is defined as the amount of antioxidant material required to scavenge $50 \%$ of free radical in the assay system. The $\mathrm{IC}_{50}$ values are inversely proportional to the antioxidant activity.

\section{Determination of Total Phenolic Content (TPC)}

Total phenolic compound assayed with a method modified after according to Li et al., (2008). Exactly $2.5 \mathrm{~g}$ of composite leaf samples were weighing out to a $250 \mathrm{~mL}$ beaker and $50 \mathrm{~mL}$ methanol added and then homogenized plant samples for 2-3 minutes using OV-5 Homogenizer, VELP, and Italy. The mixture was kept for 60 minutes in the dark condition and then the content centrifuged for 5 minutes at $5000 \mathrm{rpm}$, supernatant extract was taken for phenol determination.

Gallic acid was used here as standard. Exactly, $0.5 \mathrm{~mL}$ different concentrations of Gallic acid solutions or plant extracts were taken into a $50 \mathrm{~mL}$ test tube. Then $2.5 \mathrm{~mL}$ of 
Folin-Ciocalteu reagent and $2.5 \mathrm{~mL}$ of $\mathrm{Na}_{2} \mathrm{CO} 3(7.5 \%)$ solution was added. The mixture was kept in dark condition for half an hour at room temperature. Then absorbance was measured at $760 \mathrm{~nm}$. The absorbance value is the reflection of the total phenolics content of the compound. After plotting the absorbance in ordinate against the concentration a linear relationship was obtained which was used as a standard curve for the determination of the total phenolic content of the test samples and expressed as $\mathrm{mg}$ gallic acid equivalent (GAE)/100 g of leaf fresh weight (FW).

\section{Determination of Total Flavonoids Content (TFC)}

Flavonoid content assayed with a method modified after Kumaran and Karunakaran (2007). Exactly $2.5 \mathrm{~g}$ of composite leaf samples were weighing out to a $250 \mathrm{~mL}$ beaker and $50 \mathrm{~mL}$ methanol added and then homogenized plant samples for 2-3 minutes using OV-5 Homogenizer, VELP, and Italy. The mixture was kept for 60 minutes in the dark condition and then the content centrifuged for 5 minutes at $5000 \mathrm{rpm}$, supernatant extract was taken for flavonoid determination.

Quercetin was used here as standard. Exactly, $1 \mathrm{~mL}$ different concentrations of Quercetin solutions or plant extracts were taken into a $50 \mathrm{~mL}$ test tube. Then $3 \mathrm{~mL}$ of methanol, 200uL of $10 \% \mathrm{Alcl}_{3}, 200 \mathrm{uL}$ of $1 \mathrm{M}$ potassium acetate and $5.6 \mathrm{ml}$ distilled water was added. The mixture was kept in dark condition for half an hour at room temperature. Then absorbance was measured at $420 \mathrm{~nm}$. The absorbance value is the reflection of the total flavonoid content of the compound. After plotting the absorbance in ordinate against the concentration a linear relationship was obtained which was used as a standard curve for the determination of the total flavonoid content of the test samples and expressed as mg Quercetin acid equivalent (QUE)/100 $\mathrm{g}$ of leaf fresh weight (FW).

\section{Statistical Analyses}

The collected data were statistically analyzed by using Minitab 17. Tukey's LSD test was applied to compare the treatments means at 0.05 level of confidence. Significant differences among treatments means were determined using the Duncan Multiple Range Test (DMRT).

\section{Result and Discussion}

\section{Chlorophyll-a Content in Leaves of Ten Different Medicinal Plants}

Chlorophyll-a content in leaves varied significantly among the tested six different medicinal plants and ranged from 311.67 to $67.33 \mathrm{mg} / 100 \mathrm{gm} \mathrm{FW}$. Z. rhetsa leaf showed the highest amount of chlorophyll-a content ( $311.67 \mathrm{mg} / 100 \mathrm{gm} \mathrm{FW}$ ) followed by the second highest in $O$. indicumleaf $(299 \mathrm{mg} / 100 \mathrm{gm} \mathrm{FW})$. The lowest content of chlorophyll-a was recorded in, T. trilobatum leaf (67.33 $\mathrm{mg} / 100 \mathrm{gm} \mathrm{FW).} \mathrm{A.} \mathrm{mexicana,} C$. gigantea, $F$. carica, $G$. odorata, L. spinosa, L. aspera and R. communis, contained 101.33, 107.33, 112.33, 171.67, 176.33, 199 and 111.33 $\mathrm{mg} / 100$ gm FW respectively (Figure 1).

\section{Chlorophyll-B Content in Leaves of Ten Different Medicinal Plants \\ Chlorophyll-b content in leaves varied widely among the tested ten plants and ranged from 157 to $41.88 \mathrm{mg} / 100$}

gm FW. Leucas aspera leaf showed the highest amount of chlorophyll-b content (mg/100 gm FW) followed by the second highest in Z. rhetsa leaf (127.66 mg/100 gm FW). The lowest content of chlorophyll-b was found in $A$. mexicana leaf (mg/100 gm FW). C. gigantea, F. carica, $G$. odorata, L. spinosa, O. indicum, $R$. communis and $T$. trilobatum contained 68.67, 85.67, 121, 124.67, 120.67, 64.33 and $71.33 \mathrm{mg} / 100 \mathrm{gm}$ FW respectively (Figure 2).

\section{Total Chlorophyll Content in Leaves of Ten Different Medicinal Plants}

Chlorophyll content in leaves of ten different medicinal plants varied widely (Figure 3). Among the tested ten plants it ranged from 439 to $138 \mathrm{mg} / 100 \mathrm{gm} \mathrm{FW}$. Z. rhetsa leaf showed the highest amount of chlorophyll- $(a+b)$ content as $439 \mathrm{mg} / 100 \mathrm{gm}$ FW followed by the second highest in $O$. indicum leaf $(420 \mathrm{mg} / 100 \mathrm{gm} \mathrm{FW})$. The lowest value of chlorophyll- $(\mathrm{a}+\mathrm{b})$ content was found in $T$. trilobatum leaf (138 mg/100 gm FW). Chlorophyll-(a+b) contents of $A$ mexicana, C. gigantea, F. carica, G. odorata, L. spinosa, $L$. aspera, and $R$. communis were 143.21, 178,198, 293, 301, 356 and $176 \mathrm{mg} / 100 \mathrm{gm} \mathrm{FW}$, respectively (Figure 3)

\section{Total Carotenoids Content in Leaves of Ten Different Medicinal Plants}

Total carotenoids content in leaves varied widely among the tested ten plants and ranged from 96 to $52.67 \mathrm{mg} / 100 \mathrm{gm}$ FW (Figure 4). A. mexicana leaf showed the highest amount of carotenoids content as $96 \mathrm{mg} / 100 \mathrm{gm} \mathrm{FW}$ followed by the second highest in $F$. carica leaf $(52.67 \mathrm{mg} / 100 \mathrm{gm} \mathrm{FW})$. The lowest value of carotenoids content was found in $T$. trilobatum leaf $(7.77 \mathrm{mg} / 100 \mathrm{gm} \mathrm{FW})$. The leaves of other species showed the carotenoids content as: $C$. gigantean (18.33 mg/100 gm FW), G. odorata (19.60 mg/100 gm FW), L. spinosa $(28 \mathrm{mg} / 100 \mathrm{gm} \mathrm{FW})$, L. aspera $(34.33 \mathrm{mg} / 100$ gm FW) O. indicum (39 mg/100 gm FW) $R$. communis $(33.33 \mathrm{mg} / 100 \mathrm{gm} \mathrm{FW})$ and Z. rhetsa $(22 \mathrm{mg} / 100 \mathrm{gm} \mathrm{FW})$ (Figure 4).

\section{Radicals Scavenging Activity By DPPH}

The $\mathrm{IC}_{50}$ value (the amount of antioxidant material required to scavenge $50 \%$ of free radical in the assay system) of leaf extract to scavenge DPPH radical varied significantly among the tested ten medicinal plants and ranged from $35.37 \mathrm{mg} / \mathrm{mL}$ (A. mexicana) to $90.47 \mathrm{mg} / \mathrm{mL}$ (F. carica) (Figure 5). The $\mathrm{IC}_{50}$ values were to be 76.15 , $71.15,66.06,66.71,55.98,78.13,75.57,50.97 \mathrm{mg} / \mathrm{mL}$ for C. gigantean, G. odorata, L. spinosa, L. aspera, O. indicum, $R$. communis, T. trilobatum, and $Z$. rhetsa, respectively. The A. mexicana leaf extract demonstrated the most potent activity (Figure 5).

\section{Total Phenolic Content (TPC)}

Variation in TPC was very large, ranged from 94.53 to $484.88 \mathrm{mg}$ GAE/100 $\mathrm{g}$ fresh weight. L. aspera had total soluble phenolic content of $484.88 \mathrm{mg} \mathrm{GAE} / 100 \mathrm{~g} \mathrm{FW}$ that was the highest among all the study samples. The lowest TPC content was detected in $C$. gigantea $(94.53 \mathrm{mg}$ GAE/100 g FW) leaves. The TPC content in the extracts of analyzed portions of the assayed plants was found in the order as L. aspera $>R$. comunis $>$ Z. rhetsa $>$ L. spinosa $>$ G. odorata $>F$. carica $>O$. indicum $>A$. mexicana $>T$. trilobatum $>$ Calotropis gigantean (Figure 6). 


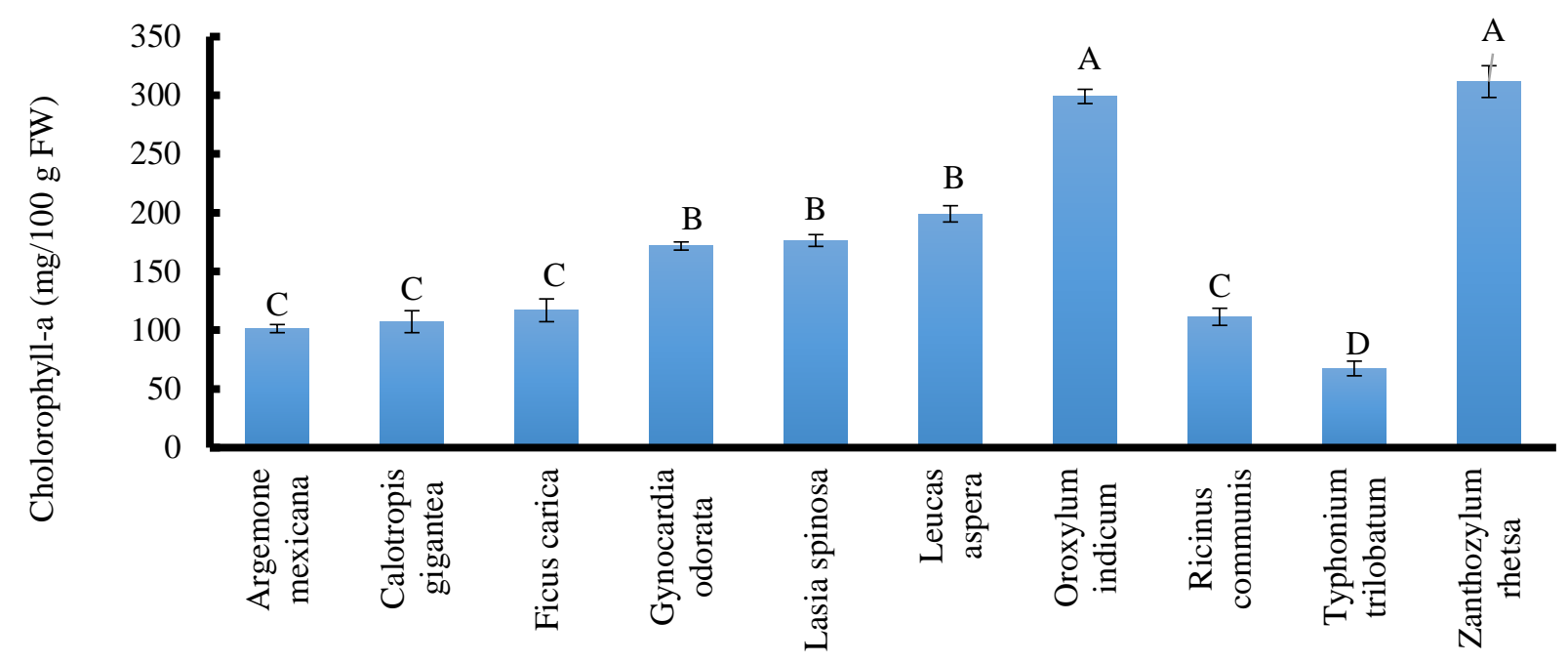

Figure 1. Chlorophyll-a content in leaves of ten different medicinal plants. Each data point is the average of three replicates \pm SEM. Bars sharing different letters are significantly different from each other at $\mathrm{P} \leq 0.05$.

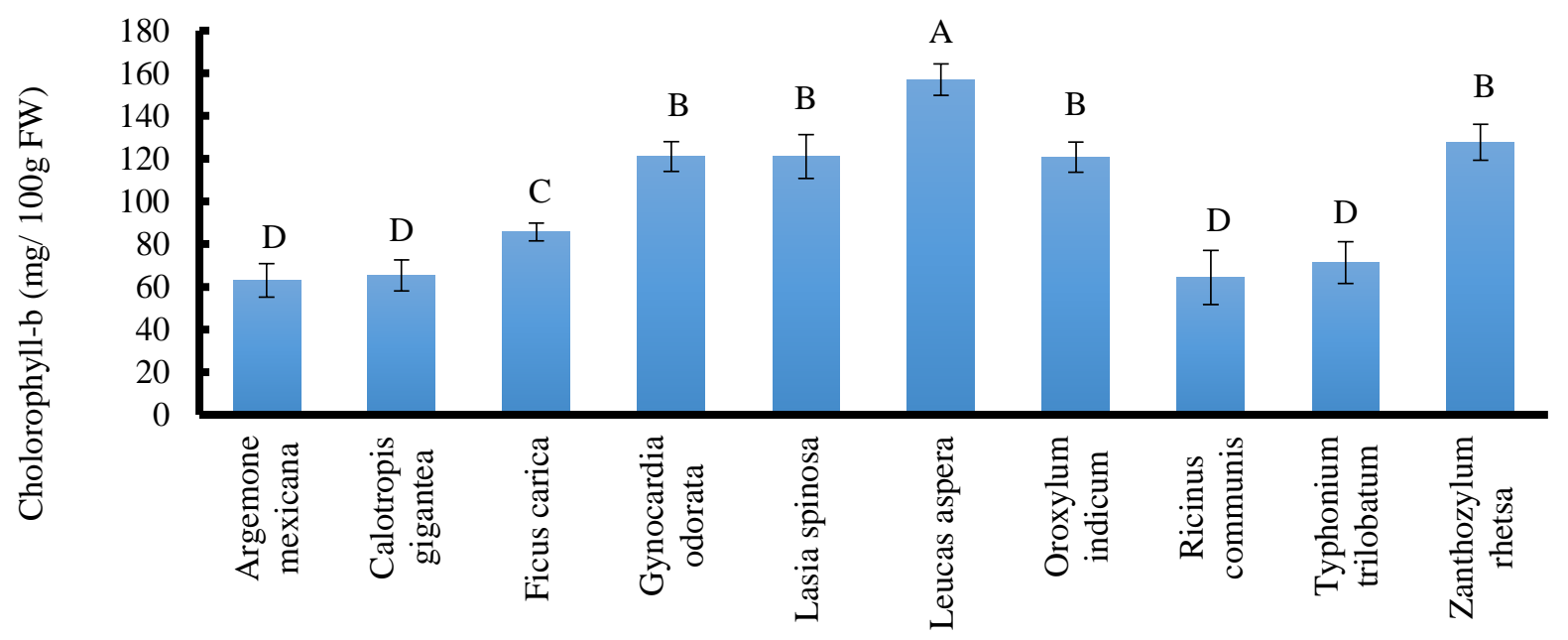

Figure 2. Chlorophyll-b content in leaves of ten different medicinal plants. Each data point is the average of three replicates \pm SEM. Bars sharing different letters are significantly different from each other at $\mathrm{P} \leq 0.05$.

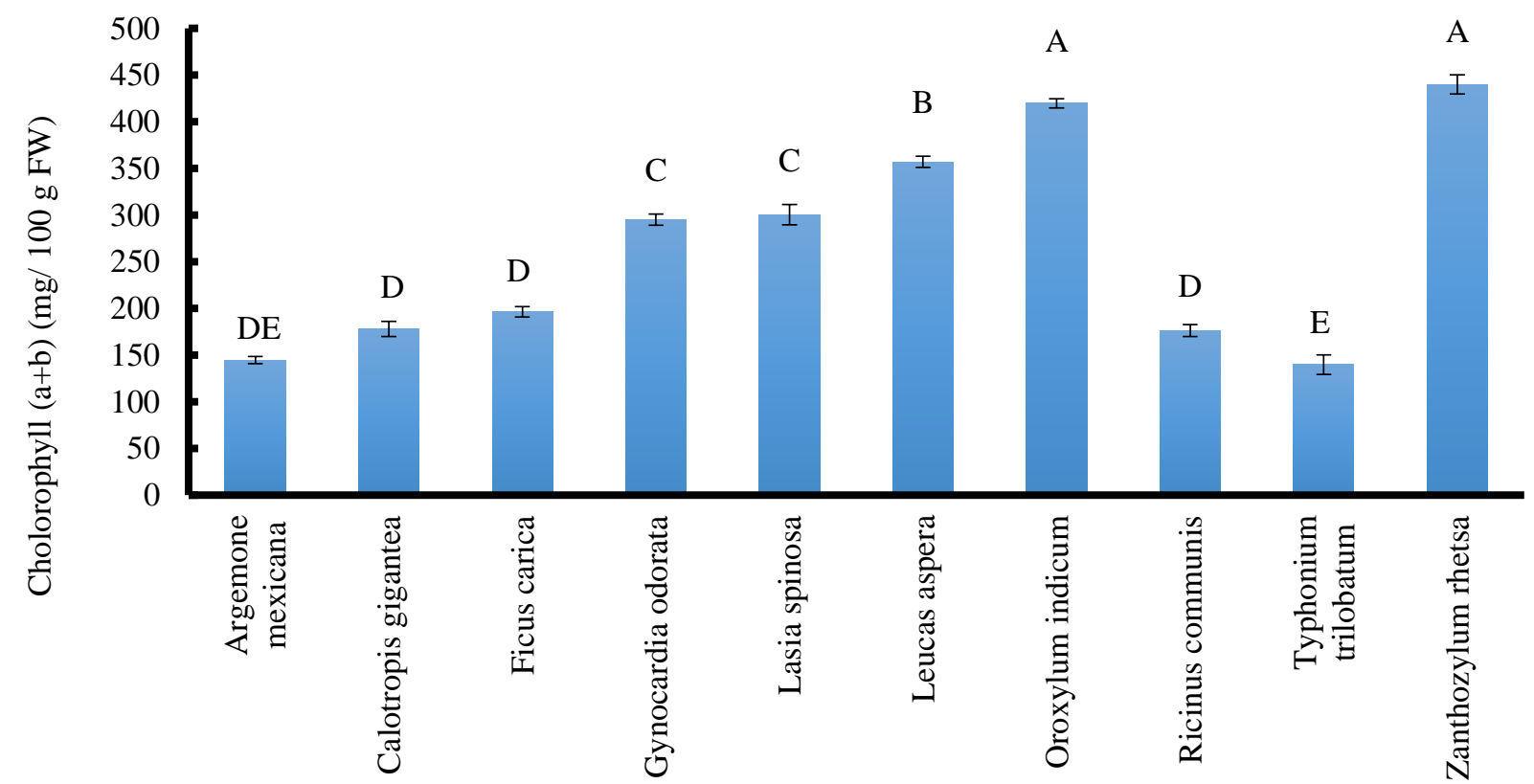

Figure 3. Chlorophyll $(\mathrm{a}+\mathrm{b})$ content in leaves of ten different medicinal plants. Each data point is the average of three replicates \pm SEM. Bars sharing different letters are significantly different from each other at $\mathrm{P} \leq 0.05$. 


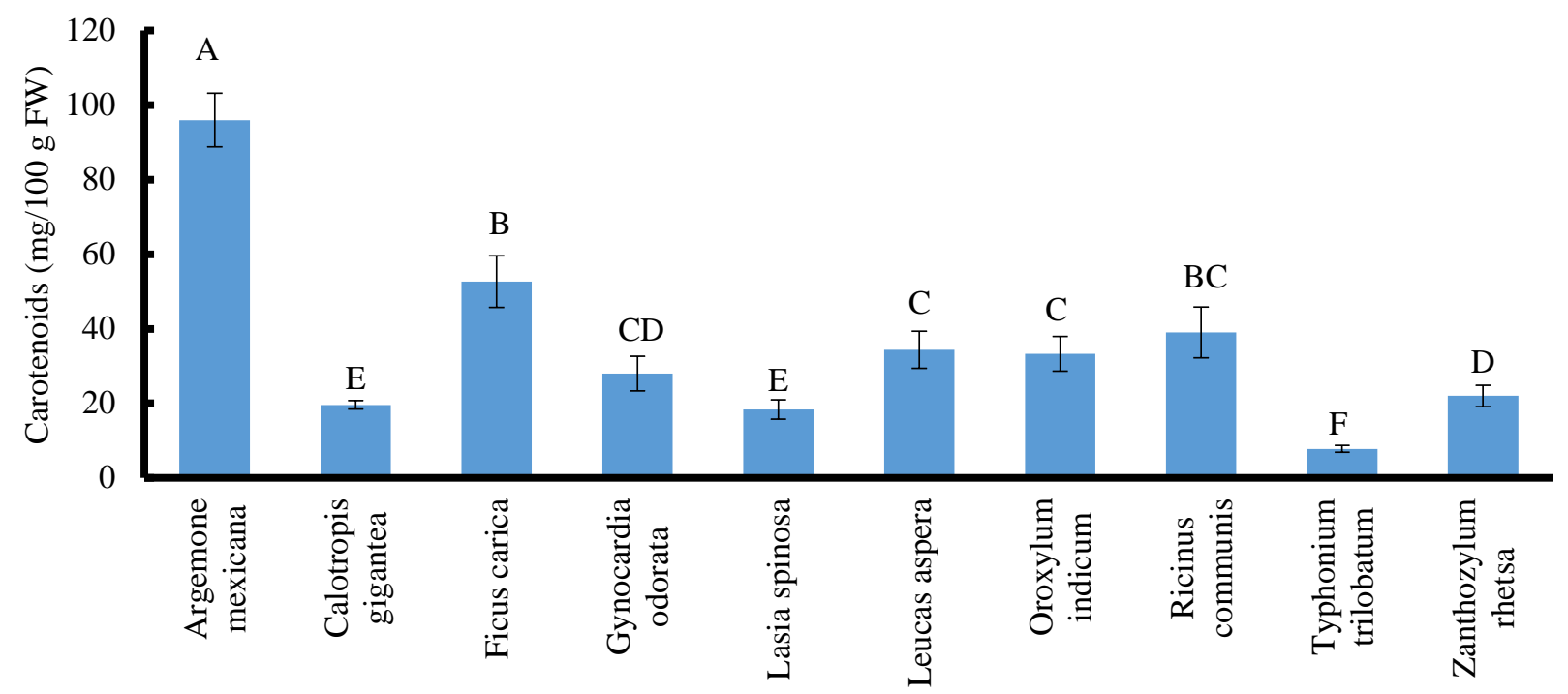

Figure 4. Amount of carotenoids in leaves of ten different medicinal plants. Each data point is the average of three replicates \pm SEM. Bars sharing different letters are significantly different from each other at $\mathrm{P} \leq 0.05$.

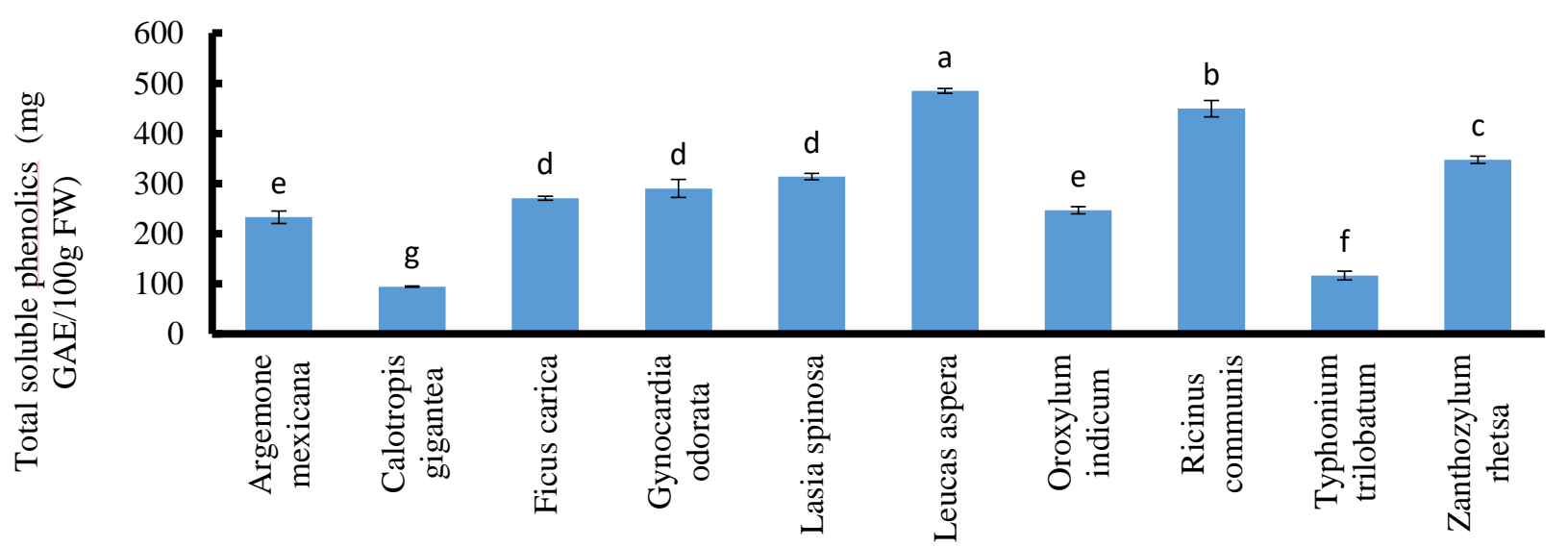

Figure 5. Total soluble phenolic content in the leaves of ten different medicinal plants. It was expressed as mg gallic acid equivalent $(\mathrm{GAE}) / 100 \mathrm{~g}$ of leaf fresh weight $(\mathrm{FW})$. Each data point is the average of three replicates $\pm \mathrm{SEM}$. Bars sharing different letters are significantly different from each other at $\mathrm{P} \leq 0.05$.

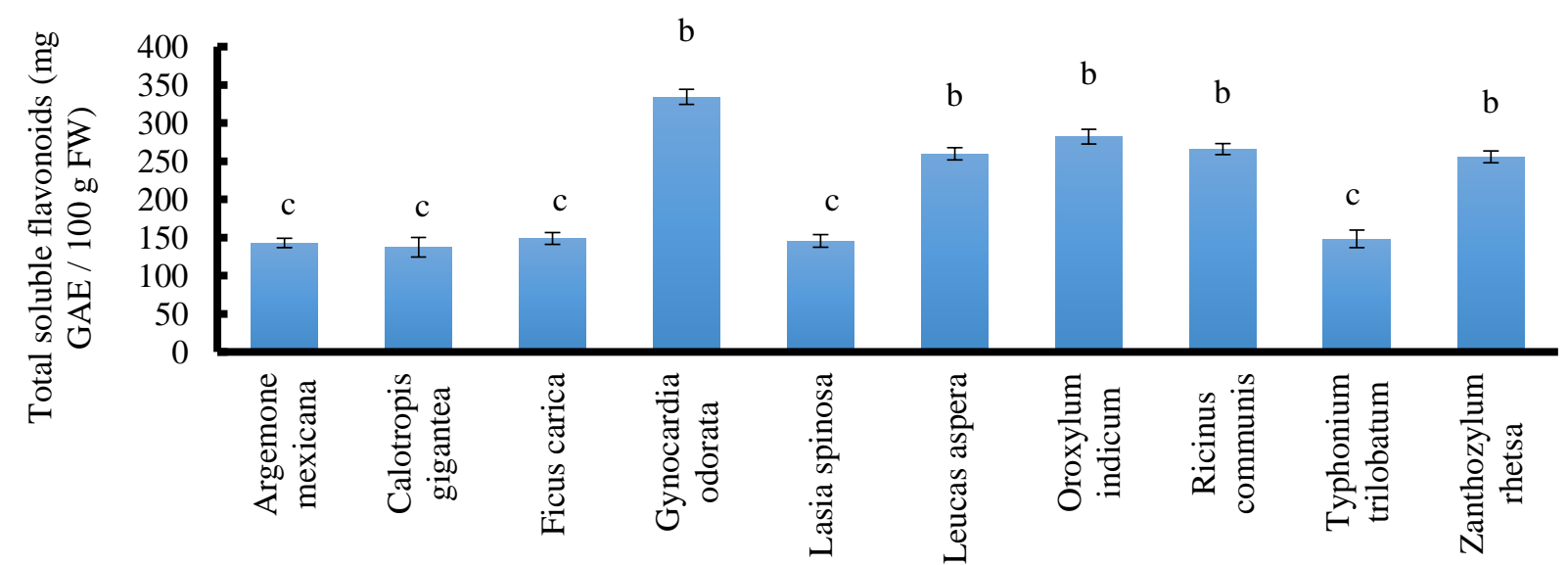

Figure 6. Total soluble flavonoid content in the leaves of ten different medicinal plants. It iswas expressed as mg Quercetin acid equivalent (QUE)/100 g of leaf fresh weight (FW). Each data point is the average of three replicates \pm SEM. Bars sharing different letters are significantly different from each other at $\mathrm{P} \leq 0.05$. 


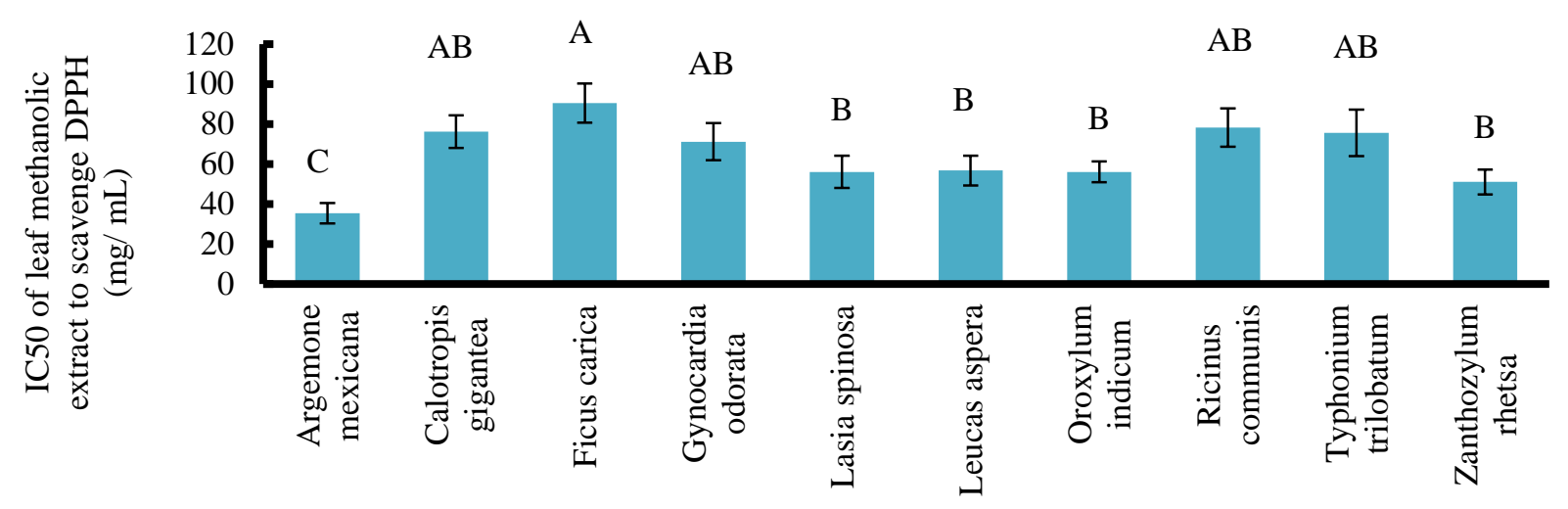

Figure 7. IC50 values for methanolic extracts of leaves from ten different medicinal plants to scavenge DPPH radical. Each data point is the average of three replicates \pm SEM. Bars sharing different letters are significantly different from each other at $\mathrm{P} \leq 0.05$.

\section{Total Flavonoids Content (TFC)}

The total flavonoid content in leaves of ten different medicinal plants varied considerably from 137.25 to $334.27 \mathrm{mg}$ QUE/100 g fresh weight (Fig. 2). G. odorata showed the highest amount of total soluble flavonoid (334.27 mg QUE/100 g FW) followed by in $O$. indicum (282.16 mg QUE/100 g FW). The lowest amount of flavonoid was detected in $C$. gigantean $(137.25 \mathrm{mg}$ QUE $/ 100 \mathrm{~g} \mathrm{FW}$ ) leaves. The total flavonoid content of the other plant extracts was $O$. indicum $>R$. communis $>L$. aspera $>$ Z. rhetsa $>F$. carica $>T$. trilobatum $>$ A. mexicana (Figure 7).

Free radicals which are mandatorily produced in normal biochemical reactions (Yen and Duh, 1994) are thought to play a critical role in many diseases such as cancer, atherosclerosis, aging, immunosuppression, inflammation, coronary heart diseases, diabetes, hair loss, and neurodegenerative disorders such as Alzheimer's disease and Parkinson's disease (Lobo et al., 2010). Dietary and other components of medicinal plants are rich sources of natural antioxidants (Lobo et al., 2010) which protects cells against degenerative effects of free radicals and thus provide healthy longer life (Ramesh and Ilyas, 2017; Polash et al 2019; Sultana et al., 2019).

The strong free radical scavenging activity exhibited by the ten plants could be attributed to high phenols, flavonoids as well as to bioactive pigments. Therefore, they can be considered as a potential source of natural antioxidants. The vital role of phenolic and flavonoids compounds as scavengers of free radical is accentuated in several reports (Madsen et al., 1996; Moller et al., 1999; Murshed et al., 2021). This thought to provide a very good antioxidant capacity due to their redox properties against free radicals, quenching singlet and triplet oxygen or decomposing peroxides as well as inhibitory effect on carcinogenesis (Dixon and Pasinetti, 2010; Sravanthi and Rao, 2015). Besides, the phenolic and flavonoids compounds possess several biological properties such as antitumor, antimutagenic and antibacterial properties, and these activities might be related to their antioxidant activity (Shui and Leong, 2002).

Photosynthetic pigments such as chlorophyll has antiinflammatory, antioxidant, and wound-healing properties. Chlorophyll is a good source of antioxidant nutrients (Lanfer-Marquez et al., 2005; Polash et al., 2018; Polash et al., 2020) Chlorophyll is an efficient deliverer of magnesium and helps the blood carry oxygen to the cells and tissue. Chlorophyll assists in the chelation of heavy metals (Hosikian et al., 2010) Chlorophyll has been studied for its potential in stimulating tissue growth and in stimulating red blood cells in connection with oxygen supply. Chlorophyll may reduce the binding of carcinogens to DNA in the liver and other organs (Ferruzzi and Blakeslee, 2007). It was proved that carotenoids have a positive role on the epithelization process and influence the cell cycle progression of the fibroblasts (Stivala et al., 1996). Carotenoids act as photoprotective agents and may reduce the risk of sunburns, photo-allergy and even some types of skin cancer (Adumanya, 2016).

\section{Conclusion}

The tested medicinal plants are the most viable and safer compared to synthetic products to protect against diseases because they have no health risks and side effects.

\section{Acknowledgement}

The authors are grateful to the head of Department of Crop Botany for their immense and cordial support. The authors are also thankful to the laboratory staff for their benign assistance.

\section{References}

Adumanya OCU. 2016. Carotenoids, Phenolics, Hydroxycinnamic Acids and Tannin Composition of Salacia senegalensis (Lam) DC Leaves. Journal of Natural Products Chemistry \& Research, 5(1): 2329-2336.

Akgul H, Korkmaz N, Dayangaç A, Sevindik M. 2020. Antioxidant Potential of Endemic Salvia absconditiflora. Turkish Journal of Agriculture-Food Science and Technology, 8(10): 2222-2224.

Ali K, Ashraf A, Biswas NN. 2012. Analgesic, anti-inflammatory and anti-diarrheal activities of ethanolic leaf extract of Typhonium trilobatum L. Schott. Asian Pacific journal of tropical biomedicine, 2(9): 722-726.

Amadò R, Abt B, Bravo L, Goñi I, Saura-Calixto F. 2002. Bioactive compounds in plant foods. Health effects and perspectives for the food industry. Cost Action. 
Ames BN, Shigenga MK, Hagen TM. 1993. Oxidants, antioxidants and degenerative diseases of aging. Proceedings of National Academy of Sciences USA, 90: 7915-7922.

Babbar N, Oberoi HS, Sandhu SK. 2015. Therapeutic and nutraceutical potential of bioactive compounds extracted from fruit residues. Critical Reviews in Food Science and Nutrition, 55(3): 319-337.

Block G, Patterson B, Subar A. 1992. Fruit, vegetables, and cancer prevention: a review of the epidemiological evidence. Nutrition and cancer, 18(1): 1-29.

Cadenas E, Davies KJ. 2000. Mitochondrial free radical generation, oxidative stress, and aging. Free Radical Biology and Medicine, 29(3-4): 222-230.

Caillet S, Salmiéri S, Lacroix M. 2006. Evaluation of free radicalscavenging properties of commercial grape phenol extracts by a fast colorimetric method. Food Chemistry, 95(1): 1-8.

Das BK, Al-Amin MM, Russel SM, Kabir S, Bhattacherjee R, Hannan JMA. 2014. Phytochemical screening and evaluation of analgesic activity of Oroxylum indicum. Indian journal of pharmaceutical sciences, 76(6): 571.

Das BS, Nanda NK. 1999. Evidence for erythrocyte lipid peroxidation in acute Falciparum malaria. Transactions of the Royal Society of Tropical Medicine and Hygiene, 93(1): 58-62.

Dash GK, Murthy PN. 2011. Evaluation of Argemone mexicana L. leaves for wound healing activity. Journal of Natural Product and Plant Resource, 1: 46-56.

Deka DC, Kumar V, Prasad C, Kumar K, Gogoi BJ, Singh L, Srivastava RB. 2013. Oroxylum indicum-a medicinal plant of North East India: An overview of its nutritional, remedial, and prophylactic properties. Journal of Applied Pharmaceutical Science, 3(4): 104-112.

Devasagayam TPA, Tilak JC, Boloor KK, Sane KS, Ghaskadbi SS, Lele RD. 2004. Free radicals and antioxidants in human health: current status and future prospects. Japi, 52: 4.

Dixon RA, Pasinetti GM. 2010. Flavonoids and isoflavonoids: from plant biology to agriculture and neuroscience. Plant Physiology, 154: 453-7.

Elliott JG. 1999. Application of antioxidant vitamins in foods and beverages: developing nutraceuticals for the new millenium. Food technology, 53(2): 46-48.

Ferruzzi MG, Blakeslee J. 2007. Digestion, absorption and cancer preventive activity of dietary chlorophyll derivatives. Nitritional Research, 27(1): 1-12.

Finkel T, Holbrook NJ. 2000. Oxidants, oxidative stress and the biology of ageing. Nature, 408(6809): 239.

Ghani A. 2003. Medicinal Plants of Bangladesh, Asiatic Society of Bangladesh. Dhaka, Bangladesh, 500-504.

Haraguchi H. 2001. Antioxidative plant constituents. Bioactive compounds from natural sources, 337-378.

Hosikian A, Lim S, Halim R, Danquah MK. 2010. Chlorophyll extraction from micro algae: A review on the process engineering aspects. International Journal of Chemistry and engineering.

Kaur C, Kapoor HC. 2002. Anti-oxidant activity and total phenolic content of some Asian vegetables. International Journal of Food Science and Technology,37(2): 153-161.

Knekt P, Järvinen R, Seppänen R, Heliövaara M, Teppo L, Pukkala E, Aromaa A. 1997. Dietary flavonoids and the risk of lung cancer and other malignant neoplasms. American journal of epidemiology, 146(3): 223-230.

Korkmaz AI, Akgul H, Sevindik M, Selamoglu Z. 2018. Study on determination of bioactive potentials of certain lichens. Acta Alimentaria, 47(1): 80-87.

Kumaran A, Karunakaran RJ. 2007. In vitro antioxidant activities of methanol extracts of five Phyllanthus species from India. LWT-Food Science and Technology, 40(2): 344-352.

Lanfer-Marquz UM, Barros RMC, Sinnecker P. 2005. Antioxidant activity of chlorophylls and their derivative. Food Research International, 38(8-9): 885-891.
Lee JY, Hwang WI, Lim ST. 2004. Antioxidant and anticancer activities of organic extracts from Platycodon grandiflorum A. De Candolle roots. Journal of Ethnopharmacology, 93(23): 409-415.

Li HB, Wong CC, Cheng KW, Chen F. 2008. Antioxidant properties in vitro and total phenolic contents in methanol extracts from medicinal plants. LWT-Food Science and Technology, 41(3): 385-390.

Lichtenthaler HK. 1987. Chlorophylls and carotenoids: pigments of photosynthetic biomembranes. In Methods in enzymology, 148: 350-382.

Lobo V, Patil A, Phatak A, Chandra N. 2010. Free radicals, antioxidants and functional foods: Impact on human health. Pharmacognosy Review, 4(8): 118-126.

Madsen HL, Nielsen BR, Bertelsen G, Skibsted LH. 1996. Screening of antioxidative activity of spices. A comparison between assays based on ESR spin trapping and electrochemical measurement of oxygen consumption. Food Chemistry, 57: 331-337

Marnett LJ. 2000. Oxyradicals and DNA damage. Carcinogenesis, 21(3): 361-370.

Mohammed FS, Sevindik M, Bal C, Akgül H, Selamoglu Z. 2019. Biological Activities of Adiantum capillus-veneris Collected from Duhok Province (Iraq). Communications Faculty of Sciences University of Ankara Series C Biology, 28(2): 128142.

Moller JKS, Madsen HL, Altonen T, Skibsted LH. 1999. Dittany (Origanum dictamnus) as a source of water-extractable antioxidants. Food Chemistry, 64: 215-219.

Pandhure N. 2014. Phytochemical Analysis and Antibacterial Activity in Ricinus communis L. Periodic Research, 3(1): 4951.

Pham-Huy LA, He H, Pham-Huy C. 2008. Free radicals, antioxidants in disease and health. International journal of biomedical science, 4(2): 89 .

Polash MAS, Sakil MA, Hossain MA. 2018. Post-harvest biodegradation of bioactive substances and antioxidant activity in microgreens. Journal of Bangladesh Agricultural University, 16(2): 250-253.

Polash MAS, Sakil MA, Sazia S, Hossain MA. 2019. Selection of suitable growing media and nutritional assessment of Microgreens. Agriculture Research Journal, 56(4); 752-756.

Polash MAS, Sakil MA, Sazia S, Rahman MA, Hossain MA. 2020. Production time and nutritional assessment of garden cress (Lepidium sativum L.) leaves for ethno-botanical uses in Bangladesh. Asian Journal of Advances in Agricultural Research, 12(4): 20-27.

Potterat O. 1997. Antioxidants and free radical scavengers of natural origin. Current organic chemistry, 1(4): 415-440.

Ramesh R, Ilyas MH. 2017. Studies on the Phytochemicals and Antioxidant Activities from Medicinal Plants by Various Methods. International Journal of Pharmacy and Pharmaceutical Research, 10(4): 67-73.

Sevindik M, Akgul H, Pehlivan M, Selamoglu Z. 2017. Determination of therapeutic potential of Mentha longifolia ssp. longifolia. Fresen Environ Bull, 26(7): 4757-4763.

Sevindik M. 2020. Antioxidant and antimicrobial capacity of Lactifluus rugatus and its antiproliferative activity on A549 cells. Indian Journal of Traditional Knowledge (IJTK), 19(2): 423-427.

Sevindik M. 2018. Pharmacological properties of Mentha species. J Tradit Med Clin Natur, 7(2): 259.

Shui G, Leong LP. 2002. Separation and determination of organic acids and phenolics compounds in fruit juices and drinks by high-performence liquid chromatography. Journal of Chromatography, 977: 89-96.

Singh S, Singh S, Mishra RM, Shrivastava MP. 2014. Preliminary phytochemical screening of Calotropis gigantea leaf. International Journal of Scientific and Research Publications, 4(2): $1-3$. 
Sravanthi J, Rao SG. 2015. Phytochemical and antioxidant composition in Lycopersicum esculentum. Journal of Medicinal Plants Studies, 3(4): 107-10.

Steinberg D. 1991. Antioxidants and atherosclerosis. A current assessment. Circulation, 84(3): 1420-1425.

Stivala LA, Savio M, Cazzalini O, Pizzala R, Rehak L, Bianchi L, Vannini V, Prosperi E. 1996. Effect of P-carotene on cell cycle progression of human fibroblasts. Oxford University Press, 17: 2395-2401.

Sultana R, Polash MAS, Sakil MA, Shorna SI, Rahman MS, Rahman MA, Hakim MA. Hossain MA. 2019. Health promoting pigments and bioactive compounds of six vegetables grown in Bangladesh. Asian Journal of Medical and Biological Research 5(4) : 280-285.

Uchida K. 2000. Role of reactive aldehyde in cardiovascular diseases. Free Radical Biology and Medicine, 28(12): 16851696.
Veberic R, Colaric M, Stampar F. 2008. Phenolic acids and flavonoids of fig fruit (Ficus carica L.) in the northern Mediterranean region. Food Chemistry, 106(1): 153-157.

Yagi K. 1987. Lipid peroxides and human diseases. Chemistry and physics of lipids, 45(2-4): 337-351.

Yen GC, Duh, 1994: Scavenging Effect of Methanolic Extracts of Peanut Hulls on Free-Radical and Active-Oxygen Species. Journal of Agricultural and Food Chemistry, 42:629-632

Yingming P, Ying L, Hengshan W, Min L. 2004. Antioxidant activities of several Chinese medicine herbs. Food chemistry, 88(3): 347-350.

Zengin G, Aktumsek A, Guler GO, Cakmak YS, Yildiztugay E. 2011. Antioxidant Properties of Methanolic Extract and Fatty Acid Composition of Centaurea urvillei DC. subsp. hayekiana Wagenitz. Records of Natural Products, 5(2): 123132. 